\title{
Evolución de las políticas de rehabilitación en Áreas de Rehabilitación Integrada en España (1978-2012)
}

\section{Evolution of urban renewal policies in Areas of Integrated Renovation in Spain (1978-2012)}

$\underline{\text { A. Hernández Aja }^{(*)}, \text { Á. Matesanz Parellada }}{ }^{(*)}$, I. Rodríguez-Suárez ${ }^{(*)}$, C. García Madruga ${ }^{(*)}$

\section{RESUMEN}

El artículo estudia la evolución de las políticas de intervención en Áreas de Rehabilitación Integral (ARI) desarrolladas en España entre 1978 y 2012. Se analiza la aparición y consolidación del concepto en la política estatal de vivienda, desde el Real Decreto 3148/1978 hasta el Plan de Vivienda 2009-2012. Por otro lado se analiza la «integralidad» de las intervenciones en áreas urbanas, mediante el estudio de veinte casos representativos, entendiendo como integral aquella intervención que actúa en la ordenación urbana, el diseño urbano y el medioambiente local, la edificación y la dimensión socioeconómica. El trabajo procede de un estudio realizado para el Ministerio de Fomento mediante convenio suscrito con el Departamento de Urbanística y Ordenación del Territorio (ETSAM, UPM) para el Análisis de las políticas estatales y europeas en materia de regeneración urbana y rehabilitación de barrios.

Palabras clave: Regeneración urbana integrada; políticas públicas; planes de vivienda; áreas de rehabilitación integral, URBAN.

\section{ABSTRACT}

The aim of this article is to study the evolution of urban intervention policies through Areas of Integrated Renovation (known by the acronym ARI in Spanish) implemented in Spain between 1978 and 2012. The analysis explores the birth and consolidation of the concept in national housing policy from Royal Decree 3148/1978 to the 2009-2012 Housing Plan. It also studies the 'integrality' of interventions in urban areas by analyzing twenty representative study cases. Integrated interventions are those that include not only urban planning but also urban design and local environment, building and socio-economical dimensions. The work is based on results extracted from previous research on the analysis of national and European policies on urban regeneration and district renovation conducted for the Ministry of Economic Development under the auspices of an agreement signed with the Department of Urban and Regional Planning (ETSAM, UPM) in 2011.

Keywords: Integrated urban regeneration; public policies; housing plans; areas of integrated renovation, URBAN.

(*) Universidad Politécnica de Madrid. Madrid (España).

Persona de contacto/Corresponding author: agustin.hernandez@upm.es (A. Hernández Aja)

Hernández Aja, A., Matesanz Parellada, Á., Rodríguez-Suarez, I., García Madruga, C. (2015). Evolución de las políticas de rehabilitación en Áreas de Rehabilitación Integrada en España (1978-2012). Informes de la Construcción, 67(EXTRA-1): mo24, doi: http://dx.doi.org/10.3989/ic.14.057.

Licencia/License: Salvo indicación contraria, todos los contenidos de la edición electrónica de Informes de la Construcción se distribuyen bajo una licencia de uso y distribución Creative Commons Reconocimiento no Comercial 3.o. España (cc-by-nc). 


\section{INTRODUCCIÓN}

Entendemos la Rehabilitación Urbana Integrada como una intervención multidimensional sobre áreas urbanas consideradas vulnerables debido a que se encuentran, o pueden llegar a caer, en procesos de deterioro, por problemas sociales, económicos, físicos y/o ambientales, que las segregan de la ciudad. Pese a la necesidad de rehabilitar, de forma integrada, la ciudad existente y pese al interés de las experiencias realizadas, podemos establecer que hasta la llegada de la última crisis inmobiliaria (iniciada en 2007) la Regeneración Urbana Integrada ha tenido, en el marco de las políticas públicas de vivienda, una presencia marginal frente a la dimensión de la obra nueva. Tras el estallido de la crisis, varias han sido las iniciativas que señalan como campo prioritario la actuación en el tejido consolidado, tanto en el nivel europeo, con la Declaración de Toledo en 2010, como en el español, con la aprobación del Plan Estatal de fomento del alquiler de viviendas, la rehabilitación edificatoria, y la regeneración y renovación urbanas y la Ley 8/2013 de rehabilitación, regeneración y renovación urbanas. La Rehabilitación Urbana Integrada pasa a formar parte central del discurso de las instituciones y los técnicos.

En este contexto, en 2011, desde el Departamento de Urbanística y Ordenación del Territorio de la Escuela Técnica de Arquitectura de Madrid, se desarrolló, gracias a un convenio con el Ministerio de Fomento, el estudio «Análisis de las políticas estatales y europeas en materia de regeneración urbana y rehabilitación de barrios», con el fin de analizar el desarrollo de las políticas públicas de intervención realizadas. El trabajo se estructuró en tres partes: el estudio del marco normativo, la localización de las Áreas de Rehabilitación Integral (ARI) realizadas en las ciudades de más de 50.000 habitantes y capitales de provincia y el análisis en profundidad de veinte casos.

Partiendo de los resultados del análisis, este artículo pretende dar una visión de la evolución de la Rehabilitación Urbana Integrada en España, a través de la evolución del marco normativo, analizando su presencia en planes de vivienda y programas específicos, y la evolución de los casos estudiados, en los que se hace especial hincapié en su desarrollo en el tiempo y la incorporación de las distintas dimensiones propias de la intervención integral (sociales, ambientales, económicas, etc.).

\section{LA POLÍTICA ESTATAL DE REHABILITACIÓN EN ÁREAS DE REHABILITACIÓN INTEGRAL 1978-2012}

Las políticas de rehabilitación en áreas urbanas se introdujeron en la política estatal de vivienda de forma paulatina desde principios de los años ochenta. Este proceso se realizó mediante la utilización de tres instrumentos diferenciados: la intervención en operaciones concretas de rehabilitación de áreas urbanas, denominadas genéricamente Áreas de Rehabilitación Integral (ARI); el establecimiento de un marco jurídico específico para la rehabilitación; y la incorporación de programas de rehabilitación en los planes estatales de vivienda. $\mathrm{Al}$ analizar cómo estos tres instrumentos se incardinaron con la política estatal de vivienda y cuáles eran las actuaciones que recibían apoyo financiero, es posible distinguir tres etapas diferenciadas.

En la primera etapa (1978-1991), la intervención en áreas urbanas se regulaba de forma independiente a los planes de vivienda. Se fijaron los rasgos principales de los programas de ARI y se iniciaron las primeras operaciones financiadas

\section{INTRODUCTION}

Integrated Urban Regeneration is understood as a multidimensional intervention in urban areas considered vulnerable as they are or could be subject to processes of deterioration caused by social, economic, physical and/ or environmental issues that segregate them from the city. Although the existing city needs to be renovated integrally and experiences to date have been interesting, until the last real estate crisis began in 2007, urban regeneration had hardly featured in public policies on housing compared with new builds. After the recession hit, several initiatives identified intervention in the consolidated urban fabric as a priority, in both Europe (Toledo Declaration, 2010) and Spain, with the approval of the State Plan for the promotion of rental housing, building renewal and urban regeneration and renovation and Act 8/2013 on urban renovation, regeneration and renovation. Integrated Urban Regeneration has become a central part of the discourse of institutions and experts.

In this context, in 2011, as a result of an agreement with the Ministry of Development, the Urban and Regional Planning Department of the Technical School of Architecture of Madrid conducted a study entitled "Analysis of national and European policies in the field of urban regeneration and district renovation". The aim was to analyze the performance of public policies. The analysis was structured into three parts: the study of the legal framework, the mapping of Areas of Integrated Renovation (ARI) in cities with over 50,00o inhabitants and the capital cities of provinces, and an in-depth analysis of twenty study cases.

This article, based on the analysis results, provides an overview of the evolution of integrated urban renewal in Spain. This is achieved by tracing, firstly, the evolution of its legal framework through an analysis of its presence in housing plans and specific programs, and, secondly, the evolution of the above-mentioned cases, focusing especially on their development over time and the incorporation of the typical dimensions of integrated intervention (social, environmental, economic, and so on).

\section{STATE RENOVATION POLICY IN AREAS OF INTEGRATED RENOVATION 1978-2012}

Renovation policies in urban areas were introduced gradually into state housing policy from the early eighties. This process was implemented using three differentiated instruments: intervention in specific renovation processes in urban areas, generically known as Areas of Integrated Rehabilitation (ARI), the establishment of a specific legal framework for renewal, and the inclusion of renovation programs in state housing plans. An analysis of how these three instruments were incorporated into the state housing policy and of the interventions that had financial support highlights three differentiated phases.

During the first phase (1978-1991), intervention in urban areas was regulated independently from housing plans. The main features of the ARI programs were then established and the first operations funded by housing 
por los planes de vivienda, dedicados básicamente a la financiación de obra nueva. La política estatal de vivienda evolucionó hasta su estabilización a principios de los años noventa, momento en el que el reparto competencial y las propias estructuras operativas se encontraron desarrolladas. Durante la segunda etapa (1992-2012), se sucedieron seis planes de vivienda, en los que la intervención en ARI se consolidó como un programa más dentro de los planes estatales de vivienda, adquiriendo complejidad con el desarrollo de los mismos. Desde 2013 la política de vivienda estatal da un vuelco y se determina como objetivo principal la rehabilitación, proceso que culmina con el establecimiento de un nuevo marco jurídico para la rehabilitación, tras la aprobación de la Ley 8/2013.

En la política y en los ciclos económicos e inmobiliarios hubo cambios sustanciales en estos treinta años, con gobiernos de la UCD, el PSOE y el PP, la incorporación de España a la Unión Europea, varias crisis económicas y dos burbujas inmobiliarias (1). A pesar de todos estos cambios, la política estatal de rehabilitación de áreas se desarrolló en el contexto de los planes de vivienda en continuidad a lo largo del tiempo, evolucionando con las propias situaciones y perfeccionando un sistema que hasta 2013 estuvo supeditado a la política de obra nueva y que aplicó recursos reducidos a la rehabilitación edificatoria, a la reurbanización y a los equipos de gestión de las áreas. El mapa completo de los instrumentos del periodo y de las actuaciones protegidas por ellos se representa en la Tabla 1.

\subsection{Legislación de Áreas de Rehabilitación Integral y planes de vivienda antes de 1992}

plans were set in motion, focusing on funding new builds. The state housing policy continued to evolve until it stabilized at the beginning of the nineties, which is when areas of responsibility and operational structures were decided upon. In the second phase (1992-2012), there was a series of six housing plans, and intervention in integrated renovation areas was included as another program in state housing plans, becoming more complex as they were implemented. Since 2013, the state housing policy has about-turned, with renovation targeted as the main objective. This process then culminated with the establishment of a new legal framework for urban renewal, after the approval of Act 8/2013.

Substantial changes took place in politics and in economic and real estate cycles in those thirty years due to the successive governments of the UCD, PSOE and PP parties; Spain's entry to the European Union; several recessions; and two real estate bubbles (1). Despite all these changes, the state district renovation policy developed in a context of a series of housing plans by reacting to specific situations and refining a system that was subordinate to the new build policy until 2013, with few resources allocated to building renewal, re-urbanization and each area's management teams. The full summary of instruments from this period and the interventions they protected are shown in Table 1.

\subsection{Legislation in integrated renovation areas and housing plans before 1992}

Tabla 1. Instrumentos de la política estatal de rehabilitación de áreas entre 1978 y 2012 y actuaciones protegidas.

\begin{tabular}{|c|c|c|c|c|c|c|c|c|}
\hline \multirow{3}{*}{$\begin{array}{c}\text { Plan de } \\
\text { vivienda }\end{array}$} & \multirow{3}{*}{ Instrumentos } & \multirow{3}{*}{ Tipo (o) } & \multicolumn{6}{|c|}{ Actuaciones protegidas } \\
\hline & & & \multirow{2}{*}{$\begin{array}{c}\text { Obra } \\
\text { nueva }\end{array}$} & \multicolumn{3}{|c|}{ Rehab. aislada } & \multirow{2}{*}{$\begin{array}{l}\text { Rehab. } \\
\text { áreas. ARI }\end{array}$} & \multirow{2}{*}{$\begin{array}{c}\text { Ofic. } \\
\text { Gestión }\end{array}$} \\
\hline & & & & Edif. & Viv. & Equip. comu. & & \\
\hline \multicolumn{9}{|c|}{ Antes de 1980. Programas de viviendas de protección oficial } \\
\hline \multirow[t]{2}{*}{$V P O$} & RD $3148 / 1978$ & PV & $\cdot$ & & & & & \\
\hline & Programa piloto (1979) & & & & & & $\cdot$ & $\cdot$ \\
\hline \multicolumn{9}{|c|}{ 1980-1991. Legislación de ARI y planes de vivienda } \\
\hline & RD-ley $12 / 1980$ & LR & & - & - & $\cdot$ & - & \\
\hline \multirow[t]{4}{*}{$1981-1983$} & RD 2455/1980 & PV & $\cdot$ & & & & & \\
\hline & RD 375/1982 & LR & & - (1) & - (1) & & & \\
\hline & RD 2555/1982 & LR & & & & - (1) & - (1) & \\
\hline & RD 2329/1983 & LR & & - (1) & - (1) & - (1) & - (1) & - (1) \\
\hline 1984-1987 & RD $3280 / 1983$ & PV & - & $\bullet$ & $\bullet$ & $\bullet$ & - (2) & - (2) \\
\hline \multirow[t]{2}{*}{$1988-1991^{*}$} & RD 1494/1987 & PV & $\cdot$ & - & - & - & - (3) & $\bullet$ \\
\hline & RD 224/1989 & $\mathrm{PV}$ & $\cdot$ & $\cdot$ & - & $\cdot$ & - (3) & - \\
\hline \multicolumn{9}{|c|}{ 1992-2012. Programa de ARI en planes de vivienda } \\
\hline \multirow[t]{2}{*}{$1992-1995$} & RD 1932/1991 & PV & $\bullet$ & $\cdot$ & $\cdot$ & $\cdot$ & - (3) & • \\
\hline & RD 726/1993 & PV & - & - & • & • & $\cdot$ & • \\
\hline $1996-1999$ & RD 2190/1995 & PV & - & • & - & - & - & • \\
\hline $1998-2001$ & RD 1186/1998 & PV & - & • & • & & - & • \\
\hline 2002-2005 & $\mathrm{RD} 1 / 2002$ & PV & $\cdot$ & - & - & & $\cdot$ & - \\
\hline \multirow[t]{2}{*}{$2005-2008$} & RD 801/ 2005 & PV & - & - & - & & - (4) & • \\
\hline & RD 14/2008 & PV & - & - & - & & - (5) & - \\
\hline 2009-2012 & RD 2066/2008 & PV & - & • & - & & - (6) & • \\
\hline
\end{tabular}

Leyenda: 1988-1991* No existió plan de vivienda, sólo programas de ayudas anuales; (o) Tipos de instrumentos: planes de vivienda (PV), legislación de rehabilitación (LR); (1) Autorización para dedicar recursos del Plan 1981-1983 a actuaciones de rehabilitación aislada o en áreas; (2) Autorización para dedicar recursos del Plan 1984-1987 a ARI reguladas por RD 2329/1983; (3) ARI sin programa independiente. Edificios, viviendas y equipamiento comunitario primario en ARI reciben financiación suplementaria; (4) ARI, áreas de rehabilitación de casco histórico ARCH; (5) ARI, ARCH, áreas de renovación urbana ARU; (6) ARI, ARCH, ARU, erradicación del chabolismo CHAB. (Elaboración propia). 
Las políticas estatales de rehabilitación urbana se desarrollaron de manera simultánea con la aprobación de las primeras operaciones de ARI y el establecimiento del marco jurídico que las regulaba. Todo ello se incorporó a los planes de vivienda, habilitando la disponibilidad de financiación para la rehabilitación de áreas. Hasta ese momento la política estatal de vivienda se había centrado exclusivamente en la obra nueva y tenía una dilatada tradición que arrancaba a principios del siglo xx (2) que desde finales de los años setenta se concretaba en programas de viviendas de protección oficial (VPO), tanto pública como privada, de urbanización y de equipamiento comunitario primario.

Cronológicamente, el primer instrumento en aparecer fue la intervención en áreas concretas. En 1979 el Ministerio de Obras Públicas y Urbanismo (MOPU) inició el Programa de operaciones piloto de actuación conjunta en áreas urbanas y asentamientos rurales y comenzó la elaboración de algunos estudios básicos de rehabilitación en tejidos centrales. $\mathrm{Al}$ mismo tiempo, se trabajaba en el establecimiento de un marco jurídico para la rehabilitación urbana. En 1980 se aprobó el Real Decreto-ley 12/1980, que ampliaba el ámbito de la protección pública a la rehabilitación de vivienda y era un adelanto de los contenidos del Proyecto de Ley de Protección Pública a la Vivienda que se encontraba en tramitación en las Cortes y que no llegó a aprobarse. Contenía, además, algunos de los instrumentos y programas básicos de la política de vivienda de los treinta años siguientes: la subsidiación de préstamos y la ampliación de la protección pública a las transmisiones de suelo, la urbanización y el equipamiento comunitario primario (edificios y espacios libres).

En 1982, y en desarrollo del RD-Ley 12/1980, se aprobaron dos reales decretos, uno dedicado a la rehabilitación aislada (RD 375/1982) y el otro a la rehabilitación de áreas (RD 2555/1982). Estos fueron derogados por un nuevo real decreto (RD 2329/1983) que regulaba ambos tipos de actuaciones y que podría considerarse como la disposición legal fundacional de la rehabilitación urbana en España. Este Real Decreto aún no ha sido expresamente derogado y, junto con la orden de 8 de diciembre de 1983 que desarrolla los procedimientos de declaración y gestión de ARI, ha sido el fundamento de los programas de rehabilitación urbana que se sucedieron en los planes de vivienda posteriores.

Respecto a las actuaciones financiables y el procedimiento de declaración, hubo cambios sustanciales entre los reales decretos de 1982 y 1983. En ambos, la declaración de ARI requería la realización de un Estudio Básico de Rehabilitación, realizado por la Dirección General de Arquitectura a petición de los entes territoriales en la regulación de 1982, y por ésta o por los entes territoriales en la de 1983. La regulación de 1982 preveía la rehabilitación de tejidos antiguos en áreas centrales, estableciendo como requisitos una antigüedad de los edificios superior a 50 años y valores arquitectónicos con riesgo de desaparición o deterioro. En 1983 se extendió la rehabilitación a cualquier ámbito de acuerdo con el planeamiento urbanístico y el estudio básico preceptivo para la declaración como ARI. Las ayudas para la rehabilitación de áreas ofrecidas durante este periodo se vinculaban a los niveles de renta de los propietarios.

En noviembre de 1982, y junto con el Real Decreto 2555/1982, se aprobaron los trece primeros estudios básicos de rehabilitación y se declararon las trece primeras ARI. En junio de 1983 se aprobaron otras tres delimitaciones. Todas ellas sobre tejidos centrales de cascos históricos.
State policies on urban renewal developed at the same time as approval of the first ARI interventions and the establishment of the legal framework regulating them. All this was incorporated in housing plans, making funds available to renovate the areas. Until that time, state housing policy had a long tradition, starting at the beginning of the twentieth century (2), of focusing solely on new builds. From the end of the sixties, the policy mainly addressed programs for subsidized housing (both public and private), urbanization and basic community facilities.

Chronologically, the first instrument to appear was intervention in specific areas. In 1979, the Ministry of Public Works and Urbanism started the Program of pilot interventions for joint action in urban areas and rural settlements, and it began to conduct some basic renewal studies in central urban areas. At the same time, efforts were made to establish a legal framework for urban renewal. In 1980, Royal Decree-Act 12/1980 was approved, expanding the reach of public protection for housing renovation and establishing the basis for the contents of the Public Protection for Housing Bill, which was never finally approved. It also contained some of the instruments and basic housing policy programs used during the following thirty years: subsidized loans, extending public protection to land transfers, urbanization and basic community facilities (for both buildings and vacant spaces).

In 1982, two royal decrees were approved to enact Royal Decree-Act 12/1980. One concerned individual renovation ( $R D$ 375/1982) and the other renovating areas ( $R D$ 2555/1982). They were repealed by a new royal decree (RD 2329/1983) that regulated both situations and could be viewed as the legal basis for urban renewal in Spain. This Royal Decree has not been expressly repealed yet and, together with the order of 8 December 1983, which implements ARI declaration and management procedures, it has laid the foundations for all the urban renewal programs in later housing plans.

Regarding interventions eligible for funding and declaration procedures, there were substantial changes between the royal decrees of 1982 and 1983. In both, the ARI declaration required a basic urban renewal study, conducted by the Directorate General of Architecture at the request of territorial entities as established in the 1982 regulation, or by the former or territorial entities in the 1983 regulation. The 1982 regulation envisioned the renewal of old urban structures in central areas by establishing as requirements that the building should be over 50 years old and an architectural asset at risk of disappearing or deteriorating. In 1983, renovation was extended to include any context in accordance with urban planning policy and the compulsory basic study for the ARI declaration. Subsidies for the renovation of areas offered during this period were linked to owners' income levels.

In November 1982, together with Royal Decree 255/1982, the first thirteen basic urban renewal studies were approved and the first thirteen ARI were declared. Three more areas were approved in June 1983. All of the interventions were on central urban structures (historic centers). 
Por su parte, la financiación pública a la vivienda se venía regulando por planes de vivienda centrados en la concesión de ayudas a la obra nueva. La transición democrática se desarrolló en el contexto de una recesión económica que produjo la aparición de un importante stock de vivienda sin vender procedente del ciclo expansivo del sector de los años sesenta y primeros setenta. Esta situación motivó el desarrollo de una política de vivienda centrada en objetivos de tipo macroeconómico, tratando de estimular desde la inversión pública la actividad en el subsector y con ella la actividad económica general y la reducción del desempleo (3).

Durante este periodo se ejecutaron dos planes de vivienda (1981-1983 y 1984-1987). Los últimos cuatro años del periodo (1988-1991), y debido a la recuperación económica del país, no se estableció programación plurianual y se instrumentaron programas anuales de ayudas. El engarce de la nueva normativa de protección a la rehabilitación en los planes se realizó habilitando parte de su financiación para las políticas de rehabilitación.

Todo este periodo supuso el establecimiento de procedimientos y un marco de colaboración entre la administración central y las comunidades autónomas y ayuntamientos, que se fue modelando con el desarrollo competencial y después de varios recursos de inconstitucionalidad interpuestos por las CCAA, que asumieron las declaraciones de áreas desde 1983. A principios de los años noventa, las políticas estatales de rehabilitación de áreas se consolidaron como un programa más en los planes cuatrienales de los años 1992 a 2012.

\subsection{La rehabilitación de áreas en los planes de vivienda durante el periodo 1992-2012}

La política estatal de rehabilitación de áreas urbanas entre 1992 y 2012 se desarrolló mediante seis planes de vivienda, en los que se introdujeron uno o varios programas dedicados a rehabilitación urbana que coexistían con múltiples programas dedicados a obra nueva, suelo, urbanización, rehabilitación aislada, alquiler, adquisición de viviendas existentes y gestión. Dos de los planes (1996-1999 y 2002-2005) no llegaron a completar su programación debido a cambios de gobierno. Las áreas de rehabilitación eran desde mediados de los años ochenta declaradas y gestionadas por las CCAA y los Ayuntamientos. El Estado establecía las condiciones financieras, las ayudas previstas y aportaba la financiación a aquellas áreas que se acordaran con cada comunidad autónoma.

Respecto a la legislación de protección a la rehabilitación, continuaba vigente el RD 2329/1983 y durante estos veinte años no se aprobó ninguna disposición legal suplementaria a los planes de vivienda. Las ARI se regulaban mediante las determinaciones contenidas en los programas de los planes.

El inicio de este periodo se encuentra en el pinchazo de la burbuja inmobiliaria de finales de los ochenta (1986-1992). En 1991 el mercado inmobiliario había experimentado una fuerte subida de precios y había caído la construcción de VPO de promoción privada, frente a esta situación el Estado recuperó la planificación plurianual abandonada en 1988. Se creó entonces un Comité de Expertos en Vivienda que elaboró el documento «Informe para una Nueva Política de Vivienda» que sirvió de base a la formulación del plan 19921995. Las medidas en él previstas se adoptaron de forma secuencial, ampliando en primer lugar en 1991 las ayudas a la adquisición onerosa de suelo. El plan aprobado en 1992
Public housing funding had been regulated by housing plans focused on granting subsidies to new builds. The democratic transition took place in an economic recession that led to the emergence of a high number of unsold housing stock resulting from the expansion of the sector in the sixties and early seventies. This situation led to the development of a housing policy focused on macroeconomic objectives to foster activity in the subsector with public investment and, at the same time, to promote general economic activity and a drop in unemployment (3).

Two housing plans (1981-1983 and 1984-1987) were implemented in this period. No multiannual programming was established in the last four years (1988-1991) in this period due to the country's economic recovery; annual funding programs were affected instead. Linking the new legal protection framework to renovation in the plans was made possible by allocating part of the funding for urban renewal policies.

This entire period involved establishing procedures and a collaboration framework between the central government and the autonomous communities and town councils. This collaboration was modeled on areas of responsibility after several appeals of unconstitutionality were lodged by autonomous communities that had been responsible for the declarations of areas since 1983. In the early nineties, state urban renewal policies for areas were consolidated as another program in the four-year plans between 1992 and 2012.

\subsection{Renovation of areas in housing plans during the 1992-2012 period}

The state urban renewal policy of urban areas between 1992 and 2012 was implemented through six housing plans. These introduced one or several programs for urban renewal that coexisted with multiple programs for new builds, land, urbanization, individual renovation, renting, acquisition of existing housing and management. Two of the plans (19961999 and 2002-2005) were not completed due to changes in government. Since the mid-eighties, renovation areas had been declared and managed by autonomous communities and town councils. The state established the financial conditions, the subsidies to be provided and funded those areas agreed with each autonomous community.

Regarding the legislation on the protection of renovation, RD 2329/1983 was still effective. For twenty years no legal provision in addition to housing plans was approved. The ARI were regulated by the content of each plan's program.

The beginning of this period coincided with the bursting of the real estate bubble in the late eighties (1986-1992). By 1991, prices had risen steeply in the real estate market and the construction of privately-developed subsidized housing had fallen. In view of this situation, the state reintroduced the multiannual planning abandoned in 1988. A committee of housing experts was created to produce the Report for a New Housing Policy. This served as a basis to draw up the 1992-1995 plan. The measures referred to in this plan were implemented sequentially. First subsidies for the onerous acquisition of land were expanded in 1991. The plan approved in 1992 (RD 1932/1992) did not include the renovation of areas as a specific program and continued 
(RD 1932/1992) no incluía la rehabilitación de áreas como un programa específico y continuaba con el sistema previo de los años 1988 a 1991 de ayudas suplementarias a los edificios y viviendas en ARI. Éste fue incorporado mediante el Real Decreto 726/1993 y fue la base de los programas de áreas de rehabilitación existentes en los cinco planes posteriores. Se eliminaba entonces la vinculación de las ayudas a rehabilitación con el nivel de ingresos de los propietarios, argumentando en el preámbulo del Real Decreto que el sistema anterior impedía el acceso a la calificación y a las ayudas en la mayoría de los casos. El funcionamiento de los planes ha permanecido invariable a lo largo del periodo 1992-2012.

La declaración de ARI, la calificación de las actuaciones como protegidas y la ejecución del plan corresponden a las CCAA. En estos veinte años los planes de vivienda se han desarrollado en un marco de colaboración estable entre el Estado y las CCAA (salvo Navarra y País Vasco debido a su régimen foral), que tiene como pieza central los convenios de colaboración para el desarrollo del Plan y una serie de órganos colegiados operativos durante su ejecución (Conferencia Sectorial de Vivienda, Consejo del Plan, Comisión Multilateral de Vivienda y comisiones bilaterales de seguimiento); aunque estos convenios se habían regulado en el periodo anterior, es en el Plan 1992-1995 cuando todas las CCAA los firman.

Durante este periodo el programa de ARI sufrió modificaciones sustanciales, aumentando su complejidad, la intensidad de las ayudas y el número de programas de rehabilitación de áreas, en función de los tejidos sobre los que se intervenga y de la intensidad de la intervención. Las declaraciones de áreas comenzaron a realizarse sobre tejidos periféricos. Los dos últimos planes incluyeron ayudas específicas para áreas de rehabilitación de casco histórico (ARCH) y áreas de renovación urbana (ARU).

También se modificó el procedimiento de gestión de las ARI. El estudio básico de rehabilitación preceptivo para la declaración de las primeras áreas se sustituyó en 1993 por la redacción de una memoria-programa que recoge el diagnóstico de la situación de deterioro del área y las medidas propuestas para su rehabilitación. Una vez declarada el área por las CCAA, el acceso a la financiación prevista en los planes se producía mediante un acuerdo suplementario.

A pesar de la complejidad de los programas de ARI y de la dilatada experiencia en su gestión, éstos supusieron una parte muy poco significativa de la inversión pública ejecutada en el periodo. Si comparamos los objetivos convenidos para los programas de rehabilitación de áreas con el total de objetivos previstos por los convenios entre 1992 y 2012, éstos suponen solamente un $6,1 \%$ respecto al total. Si la comparación se establece respecto al total de la producción inmobiliaria del periodo, los programas de ARI sólo supusieron un 1,79\% del total de viviendas ejecutadas entre 1992 y 2012 (4).

\section{LA PRÁCTICA DE LA REHABILITACIÓN EN ÁREAS URBANAS A TRAVÉS DEL ANÁLISIS DE VEINTE CASOS}

La evolución de la práctica española en el campo de la rehabilitación en áreas urbanas, no puede reducirse al análisis de su aparición en el cuerpo normativo de la política de vivienda. Nos encontramos frente a una práctica dual. Por un lado se produce la incorporación paulatina de la rehabilitación en áreas urbanas al marco económico de una financiación esta- with the previous system from the 1988-1991 period of additional subsidies for ARI buildings and housing. This last feature was implemented by Royal Decree 726/1993, and formed the basis of the existing renovation areas programs in the following five plans. The link between funding and owners' income level was, therefore, removed, and the preamble of the Royal Decree argued that the previous system prevented access to classification and subsidies in most cases. The plans' mode of operation remained the same in the 1992-2012 period.

The ARI declaration, the classification of interventions as protected and the implementation of the plan are assigned to autonomous communities. In these twenty years, housing plans have developed in this stable collaboration framework between the state and autonomous communities (except for Navarre and the Basque Country, due to their regional code of laws). The core element of the framework has been collaboration agreements to implement the plan and several official bodies to oversee implementation (Housing Sector Conference, the Plan Council, the Multilateral Housing Committee and bilateral monitoring committees). Although all these agreements were regulated in the previous period, it was not until the 1992-1995 plan that all the autonomous communities signed them.

During this period, the ARI program was altered substantially. It became more complex, the subsidy amount and the number of areas renovation programs increased based on the type and extent of the intervention. The declaration of areas started in suburban locations. The last two plans included specific funding for renovation areas inside historic city centers and urban renovation areas (programs known by their acronyms ARCH and ARU, respectively, in Spain).

The ARI management procedure was also modified. The compulsory basic urban renewal study for the declaration of the first areas was replaced in 1993 by the drafting of a report-program containing a diagnosis of the deteriorated situation of the area and the measures proposed to renovate it. Once the area had been declared by the autonomous community, the earmarked funding was accessed through a supplementary agreement.

Despite the complexity of the ARI programs and extensive experience in managing them, they represented an insignificant part of public investment in that period. If we compare the agreed objectives for the areas renovation programs with the overall objectives foreseen in the agreements between 1992 and 2012, they represent only 6.1 per cent of the total. If the comparison takes into consideration the real estate production of the period, the ARI programs only amounted to 1.79 per cent of the overall housing built between 1992 and 2012 (4).

\section{RENOVATION PRACTICE IN URBAN AREAS: THE ANALYSIS OF TWENTY CASES}

The evolution of Spanish urban area renovation cannot be limited to an analysis of how this practice is perceived in the legal housing policy framework since it has two facets. On the one hand, we have the slow but steady inclusion of renovation in urban areas in an economic context of state funding that mainly focuses on new builds, and that 
tal dedicada mayoritariamente a la producción de obra nueva y que fue ampliando el campo de las actividades protegibles, edificación, urbanización, oficinas de gestión, etc., hasta que la crisis inmobiliaria convierte la rehabilitación en la política estrella. Pero en paralelo la práctica real de la intervención demuestra, en algunos casos, una vocación de «integralidad», en la que el objetivo no era tan solo la mejora física de edificios y espacios urbanos, sino que incluía su reincorporación a la ciudad y la reducción de los problemas socioeconómicos de sus habitantes. Como ejemplo del desarrollo y consolidación de esta práctica multidimensional presentamos la evolución de las herramientas y campos de actuación en veinte casos característicos.

\subsection{Metodología de análisis de casos}

Los resultados aquí aportados proceden de un estudio en profundidad de las experiencias analizadas y que se completó con la visita a los barrios y la realización de entrevistas con agentes implicados en el proceso. La metodología empleada parte del concepto de Rehabilitación Urbana Integrada anteriormente definido, distinguiendo tanto las áreas temáticas a las que han ido dirigidas las acciones realizadas, cómo su articulación o integración, analizándose complementariamente las formas de gestión y el grado de participación de los agentes implicados.

Desde el punto de vista del análisis de la «integralidad» de las intervenciones determinamos cuatro dimensiones:

- Ordenación urbana y territorial, ligada a los temas de planeamiento, integración en la ciudad, en la que se incluyen tanto la utilización de instrumentos de planeamiento como los planes generales y especiales, tanto de rehabilitación como de protección o patrimonio.

- Diseño urbano y medio ambiente local, recoge los temas medioambientales, y los vinculados al diseño del espacio público, incluyendo planes de movilidad, de reurbanización y mejora del espacio público y el medioambiente urbano.

- Edificación, en todas estas operaciones resulta fundamental la rehabilitación de viviendas y en algún caso los equipamientos.

- Socio-economía, incluye los programas de fomento del desarrollo económico y social en el área, fomentando la implantación de empresas, la formación, o la inserción, incluyendo procesos participativos.

La elección de los veinte casos que constituyen el cuerpo de estudio, se hizo entre el conjunto de las operaciones de rehabilitación financiado por los programas ARI o URBAN entre 1992 y 2010, se basó en seis criterios: 1) coincidencia con áreas incluidas en los catálogos, de 1991,2001 o 2006 de Barrios Vulnerables del Ministerio de Fomento (5), 2) distribución geográfica; 3) variedad en sus orígenes y formas de crecimiento, 4) que fueran operaciones de cierta trayectoria que permitirán analizar los programas desarrollados, 5) coincidencia con Buenas Prácticas del programa Hábitat y 6) la opinión de un panel de expertos en rehabilitación urbana. Lo que permitió seleccionar las veinte operaciones mostradas en la Tabla 2, que pretenden cubrir el espectro de las actuaciones desarrolladas en estos años.

De los veinte casos analizados diez son operaciones en tejidos históricos (cascos o arrabales), principal objeto de las políticas de rehabilitación hasta la fecha. Estos barrios, then continued to extend the range of protected actions, building, urbanization, management offices, and so on, until the real estate crisis turned urban renewal into its star policy. However, in parallel, real intervention practice is all-inclusive in some cases, and the objective was not only physically upgrading buildings and urban spaces, but also reincorporating them into the city, and reducing their inhabitants' socioeconomic problems. As an example of the consolidation and development of this multidimensional practice, we present the evolution of the instruments and areas of focus in twenty specific cases.

\subsection{Analysis methodology of the cases}

The results compiled here come from a thorough study of the experiences we analyzed. This was accomplished by visiting the urban areas and interviewing the agents involved in the process. The methodology used is based on the abovementioned concept of Integrated Urban Regeneration and identifies the type of areas the interventions have targeted and how they were structured and integrated. It also analyses modes of management and the level of participation of the agents involved.

From the point of view of the 'integrality' of the interventions, we can determine four dimensions:

- Territorial and urban planning, related to planning and city integration topics, which include the use of planning instruments such as general and special plans for both renovation and protection of heritage.

- Urban design and local environment, which includes environmental issues, and topics related to the design of public spaces, including mobility plans, reurbanization and upgrading of public spaces and the urban environment.

- Buildings, which includes the renovation of housing, fundamental in all these interventions, and the renovation of community facilities in some cases.

- Socio-economics, which includes programs promoting the economic and social development of the area, fostering the establishment of businesses, training, labor market integration and even collaboration processes.

The twenty study cases forming the body of study were chosen from among all the urban renewal interventions funded by ARI or URBAN programs between 1992 and 2010 on the basis of six criteria: 1) coincide with areas included in the 1991, 2001 or 2006 catalogues of vulnerable districts of the Ministry of Development (5); 2) geographical distribution; 3) variety in their origins and growth patterns; 4) the fact that they were interventions of some length, thus enabling an analysis of the implemented programs; 5) coincide with the good practices of the Habitat program; and 6) the opinion of a group of experts in urban renewal. The above allowed us to select the twenty interventions shown in Table 2, and cover the spectrum of interventions implemented in these years.

Out of the twenty cases we analyzed, ten were interventions in historic urban areas (historic centers and suburbs), as these have been the main recipients of urban renewal 
Tabla 2. Características de las operaciones de rehabilitación analizadas.

\begin{tabular}{|c|c|c|c|c|c|c|c|}
\hline CASO & CIUDAD & FFCC & ORIGEN & BBVV & ARI & URBAN & OTRO \\
\hline CH de Lleida & Lleida & $\mathrm{CH}$ & A. s. XIX & & $\Delta$ & & \\
\hline CH de Logroño & Logroño & $\mathrm{CH}$ & A. s. XIX & & $\Delta$ & & \\
\hline CH Santiago de Compostela & $\begin{array}{l}\text { Santiago de } \\
\text { Compostela }\end{array}$ & $\mathrm{CH}$ & A. s. XIX & & $\Delta$ & & \\
\hline CH de Cartagena & Cartagena & $\mathrm{CH}$ & A. s. XIX & & $\Delta$ & & \\
\hline Lavapiés & Madrid & $\mathrm{CH}$ & A. s. XIX & & $\Delta$ & & \\
\hline B. del Arrabal & Zaragoza & $\mathrm{CH}$ & A. s. XIX & & $\Delta$ & & \\
\hline Bilbao La Vieja & Bilbao & $\mathrm{CH}$ & A. s. XIX & & & & \\
\hline $\mathrm{CH} /$ Rochapea & Pamplona & $\mathrm{CH}$ & A. s. XIX & & & & \\
\hline Trinidad-Perchel & Málaga & MMIX & A. s. XIX & & $\Delta$ & & \\
\hline Río de la Pila & Santander & $\mathrm{CH}$ & s. XIX & & $\Delta$ & & \\
\hline Poble Sec & Barcelona & ENS & s. XIX & & $\Delta$ & & \\
\hline La Soledad y Polígono Levante & Palma & PP/PMIX & s. $\mathrm{xIX} / 40 \mathrm{~s}$ & & $\Delta$ & & \\
\hline Urban Mérida & Mérida & PMIX & $40 s$ & & & $\Delta$ & \\
\hline Ciudades del Acero. & Avilés Corvera & PMIX & $40 s-50 s$ & & $\Delta$ & $\Delta$ & \\
\hline La Rondilla & Valladolid & PR40-60 & $50 \mathrm{~s}$ & & $\Delta$ & & \\
\hline San Cristóbal de los Ángeles & Madrid & PR4O-60 & $50 \mathrm{~s}$ & & $\Delta$ & & \\
\hline B. Zona Norte & Alicante & PMIX & $50 \mathrm{Os}$ & & $\Delta$ & $\Delta$ & \\
\hline Santa $\mathrm{M}^{\mathrm{a}}$ de Benquerencia & Toledo & PR 75-90 & $50 \mathrm{Os}$ & & $\Delta$ & & \\
\hline Santa $\mathrm{M}^{\mathrm{a}}$ del Mar & Tenerife & PR 60-75 & $60 \mathrm{~s}$ & & $\Delta$ & & \\
\hline Polígono Sur & Sevilla & PMIX & $60 \mathrm{~s}$ & & $\Delta$ & & \\
\hline
\end{tabular}

Leyenda: FFCC: forma de crecimiento; CH: Centro Histórico; ENS: Ensanche; PMIX: Periferia Mixta; MMIX: Media Mixta; PR 40-60: Promociones públicas de los años 40 a 60; PR 60-75: Promociones de los años 60 a 75; PR 75-90: Promociones públicas de los años 75 a 90. ORIGEN: época desarrollo urbano; A. s. xIX: Antes del siglo xIX.; BBVV: Coincidencia con algún Barrio Vulnerable de los catálogos de 1991 o 2001. ARI: con financiación del programa estatal ARI; URBAN: con financiación europea del programa URBAN; OTROS: con financiaciones de otros programas. $\Delta$ : Operación considerada principal por corresponder con los programas analizados. (Elaboración propia).

comparten una posición central en la ciudad, un tejido urbano irregular, y una edificación generalmente de baja altura en mal estado de conservación, independientemente de que, en muchos casos, hubiera sido sustituida en etapas posteriores.

Dos de las experiencias tienen su origen en el siglo xix, Poble Sec, y el Barrio de La Soledad de Palma (analizado junto al Polígono Levante, por conformar una única unidad de intervención). Ambos barrios, a pesar de la diferencia entre sus tejidos y densidades, nacieron de la necesidad de vivienda para obreros.

Los ocho casos restantes tienen su origen en el siglo xx: seis de ellos surgieron para albergar a la población llegada del campo, y dos, Santa María de Mar en Santa Cruz de Tenerife y el Polígono Sur de Sevilla, para albergar a población marginal de otras zonas de la ciudad. Son resultado de una suma de promociones, generalmente públicas, que se iniciaron con parcelaciones ilegales y autoconstrucción, sustituidas posteriormente por promociones unitarias. Se caracterizan por la falta de equipamientos y/o infraestructuras que fueron solventados en parte, en los años setenta.

\subsection{La «integralidad» de las operaciones de rehabilitación}

El análisis de las veinte experiencias seleccionadas se ha sintetizado gráficamente (Figuras 1 y 2) según los periodos establecidos, antes de 1992 y de 1992 a 2012. Cada cuadro recoge las experiencias esquematizando la cronología para cada una de ellas, del inicio de los planes y programas asociados a las cuatro áreas básicas, incluyendo en su caso programas integrales que atienden a más de un área. policies to date. These districts share a central position in the city, an irregular urban structure, and are generally low buildings in a poor state of repair, regardless of the fact that they were often replaced in later stages.

Two of the experiences originated in the nineteenth century, Poble Sec and La Soledad de Palma district (analyzed together with Polígono Levante, as they formed a single intervention unit). Despite the difference between their urban structures and densities, both districts were established out of the need to house workers.

The other eight cases date back to the twentieth century: six of them were built to house the population coming from the countryside, and two, Santa María de Mar in Santa Cruz de Tenerife and the Poligono Sur in Seville, to provide shelter for the deprived population from other areas of the city. They are the result of a number of generally public developments that began with illegalplot divisions and self-builds. Thesewere later replaced by unitary developments. They were characterized by a lack of community facilities and/or infrastructure, a problem that was partially solved in the seventies.

\subsection{The 'integrality' of the urban renewal interventions}

The analysis of the twenty selected experiences has been synthesized graphically (Figures 1 and 2) in accordance with the established periods, before 1992 and between 1992 and 2012. Each table schematizes the chronology of every experience, from the beginning of the plans and programs associated with the four basic areas, including the comprehensive programs implemented in more than one area, if applicable. 


\subsubsection{Actuaciones previas a 1992}

El inicio de las primeras intervenciones analizadas no se produce hasta finales de los setenta, aunque los antecedentes de éstos se remontan a las iniciativas de protección patrimonial de algunos cascos históricos a mediados y finales de los sesenta, como el de Pamplona.

Estas acciones de protección patrimonial, coetánea con algunos planes urbanísticos de naturaleza «renovadora» como los de Zaragoza o Málaga, dieron paso, con la llegada de los ayuntamientos democráticos, a una serie de planes generales y especiales de protección y/o de reforma interior, que ligados a los decretos de 1982 y 1983, iniciaron los primeros procesos de rehabilitación. Entre los acontecimientos que motivaron la redacción y aprobación de estos planes destacan fundamentalmente dos:

- el mal estado de la edificación, principalmente en los centros históricos que en algunos casos, favorecido por las demoliciones de los planes de renovación, había provocado hundimiento de viviendas y la muerte de algunos residentes, como en Lleida o Logroño.

- el movimiento vecinal, que desde los años setenta reivindicaba bien la permanencia en su barrio como reacción a los planes que promovían la completa transformación de tejidos históricos, como en Trinidad Perchel, bien la mejora y la incorporación de infraestructuras y equipamientos en barrios más recientes pero con grandes carencias, como La Rondilla o San Cristóbal de los Ángeles.

La mayoría de las acciones puestas en marcha en este periodo, se concentran en los cascos históricos (Figura 1), que, casi en su totalidad, inician sus procesos de rehabilitación entre 1979 y 1990. Una de las principales razones aducidas en sus memorias era la urgente intervención en la edificación, por lo que aparecen ligados desde sus inicios a la instalación y puesta en marcha de las primeras oficinas de rehabilitación (como en Pamplona y Logroño) y a la declaración de las primeras ARI. Ejemplo de ello es Trinidad-Perchel, que tras su inclusión en el Programa de operaciones piloto de actuación conjunta en áreas urbanas y asentamientos rurales, fue declarada ARI en 1983.

En este periodo se iniciaron procesos de mejora en algunas de las promociones estudiadas de los años cincuenta y sesenta, que a diferencia de los iniciados en los cascos históricos, se centran en las infraestructuras y la urbanización o re-urbanización de las calles. Únicamente, en el caso de San Cristóbal de los Ángeles, tras la aprobación sucesiva de planes de pavimentación, remodelación y reparación de la urbanización, se aprueba en 1986 un proyecto de reparación de las viviendas.

En relación a la «integralidad» de las actuaciones de este primer periodo, podemos establecer que éstas se dirigieron esencialmente a la ordenación urbana y en menor medida a la intervención en la edificación. A pesar de la existencia de algunas actuaciones de infraestructuras y urbanización, no se puede considerar que aparezcan actuaciones con visión medioambiental, ni programas sociales y económicos específicos. En esta época hay que señalar la aparición del Plan Piloto de Rehabilitación de Santiago de Compostela (1990), primera intervención con voluntad de integrar las medidas orientadas a la rehabilitación de viviendas en paralelo al desarrollo de programas sociales y de reactivación económica y de conservación del patrimonio (6).

\subsubsection{Interventions before 1992}

The first interventions we analyzed did not start until the end of the seventies, although the principle of renovation dates back to heritage protection initiatives in some historic centers in the mid to late sixties, for example Pamplona.

These heritage protection actions, contemporary with some "renewing" urban plans (for instance Zaragoza's or Malaga's), once democratic town councils had arrived, led to a series of general and special protection and/or interior refurbishment plans. Together with the decrees of 1982 and 1983, they started the first renovation processes. Two events stand out among those that resulted in the drafting and the approval of these plans:

- The poor state of buildings, mainly in city centers. In some cases, where the demolitions in the renovation plans had weakened the buildings further, some collapsed resulting in the death of residents (this occurred in Lleida and Logroño)

- The neighbourhood movement, whereby, since the seventies, residents had demanded either to remain in their district as a reaction to plans that supported a complete transformation of historic areas, as in Trinidad Perchel, or an upgrade and implementation of infrastructures and community facilities in more recent districts that have major deficiencies, as in La Rondilla and San Cristóbal de los Ángeles.

Most of the actions carried out in this period focused on historic centers (Figure 1) and almost all of them started their renovation processes between 1979 and 1990. One of the main reasons given in the reports was the urgent need to upgrade buildings. That is why they are linked, from the beginning, to the establishment and start-up of the first renovation offices (Pamplona and Logroño) and the first ARI declaration. A good example of this is Trinidad Perchel, which was declared an ARI in 1983 after being included in the Program of pilot interventions for joint action in urban areas and rural settlements.

In this period, upgrade processes commenced in some of the developments dating from the fifties and sixties. Unlike the ones started in city centers, these focused more on infrastructures and on urbanization and re-urbanization of streets. Only in the case of San Cristóbal de los Ángeles was a housing renovation program approved in 1986, after a series of paving, redevelopment and repair plans had been affected.

Regarding the 'integrality' of the interventions in this first period, we can establish that they essentially targeted urban planning and, to a lesser extent, intervention in buildings. Although there were some interventions in urban infrastructures and urbanization, we cannot classify them as interventions with a specific environmental, social and economic slant. The Pilot renovation plan of Santiago de Compostela appeared in this period (1990). It was the first plan to integrate measures to renovate housing in parallel to the execution of social and economic reactivation and heritage preservation programs (6). 


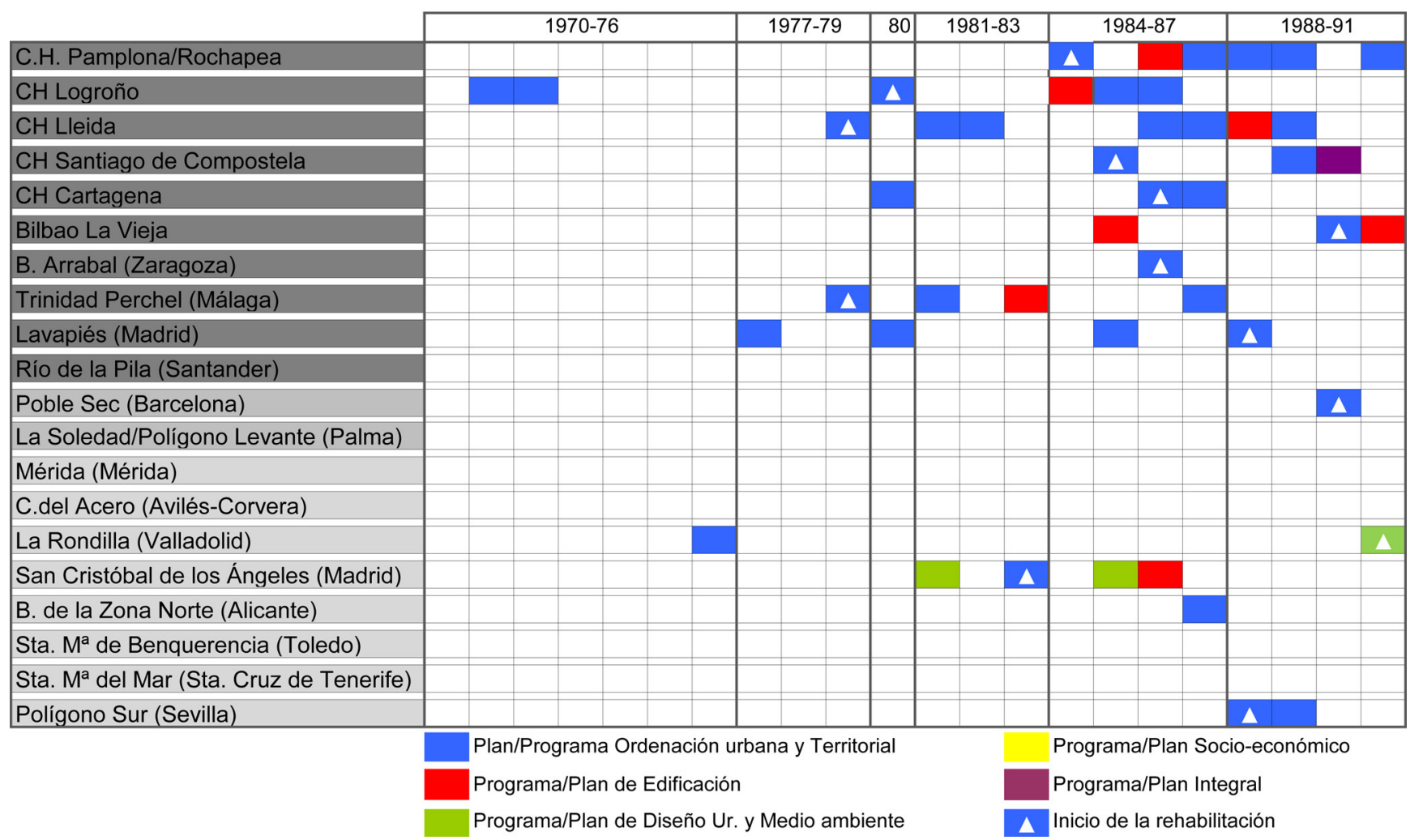

Figura 1. Actuaciones en las operaciones analizadas por área de actuación y año de inicio o aprobación, 1970-1991 (elaboración propia).

\subsubsection{Intervenciones en el periodo $1992-2012$}

A partir de 1992 se produce la explosión de planes y proyectos en las múltiples dimensiones de la «integralidad» urbana, y la ampliación de las actuaciones del centro histórico a las periferias urbanas. En la primera década del periodo se aprueban tres planes estatales de vivienda (apareciendo las ARI como un programa independiente), en coincidencia con los dos primeros programas europeos: los Proyectos Pilotos Urbanos (1989-1996) y el URBAN I (1994-1999). En esta década se iniciaron ocho procesos de rehabilitación urbana de los veinte estudiados, seis en la periferia (Figura 2). Mientras en la etapa anterior, la mayor parte de los procesos se iniciaron mediante una figura de planeamiento urbano, no fue así en este periodo. Tres de los casos iniciaron estos procesos mediante planes de ayudas para la rehabilitación de edificios: Avilés-Corvera (ARI del plan 1992-1995), Soledad-Polígono Levante (ARI del plan 1998-2001), y Río de la Pila en Santander (Plan de fachadas). Otros tres casos, Barrios Zona Norte de Alicante, Santa María del Mar y Mérida, lo hicieron, a través de planes especiales de reforma. Y por primera vez, a través del programa URBAN I, da comienzo una operación que busca desde el primer momento un enfoque integral; la del polígono de Santa María de Benquerencia en Toledo.

En el resto de las operaciones iniciadas en el periodo anterior, aumenta el número y la variedad de planes y acciones. Crecen las orientadas a la mejora de la edificación, vinculadas a la declaración de nuevos ARIs (Santiago, Lleida, Trinidad Perchel, Lavapiés, Cartagena y San Cristóbal de los Ángeles). Aparecen los programas dentro del área Socio-económica, siendo el Plan Estrategico de Bilbao Metropolitana (1992) el primero de carácter económico (que incluye toda la ciudad), y el primero de corte social, el Pla de Futur (1995) de Poble Sec. Aumentan las actuaciones en el área de Diseño Urbano y Medio Ambiente Lo-

\subsubsection{Interventions between 1992 and 2012}

The number of plans and projects concerning the multiple dimensions of urban 'integrality' exploded from 1992, and interventions expanded from city centers towards the suburbs. In the first decade of this period, three state housing plans were approved (the ARI was an independent program), coinciding with the first two European programs: Urban Pilot Projects (1989-1996) and URBAN I (1994-1999). In this decade, eight urban renovation processes started (out of the twenty we studied), six in the suburbs (Figure 2). Although most of the processes in the previous period began as a result of urban planning, this did not happen in this period. Three of the cases started these processes through funding plans for building renovation: Avilés-Corvera (ARI from the 1992-1995 plan), Soledad-Polígono Levante (ARI from the 1998-2001 plan), and Río de la Pila in Santander, (facade plan). Another three cases, the districts Zona Norte in Alicante, Santa María del Mar and Mérida, carried out the processes through special renovation plans. And for the first time, through the URBAN I program, an intervention began seeking an integral approach right from the start: Santa María de Benquerencia estate in Toledo.

The number and range of plans and actions grew in the other interventions started in the previous period. Building upgrades linked to the declaration of new ARIs increased (Santiago, Lleida, Trinidad Perchel, Lavapiés, Cartagena and San Cristóbal de los Ángeles). Programs began to appear within the socio-economic area; the Strategic Plan of Metropolitan Bilbao (1992) was the first economic one (which also included the whole city); and Pla de Futur (1995) in Poble Sec was the first social one. Interventions 


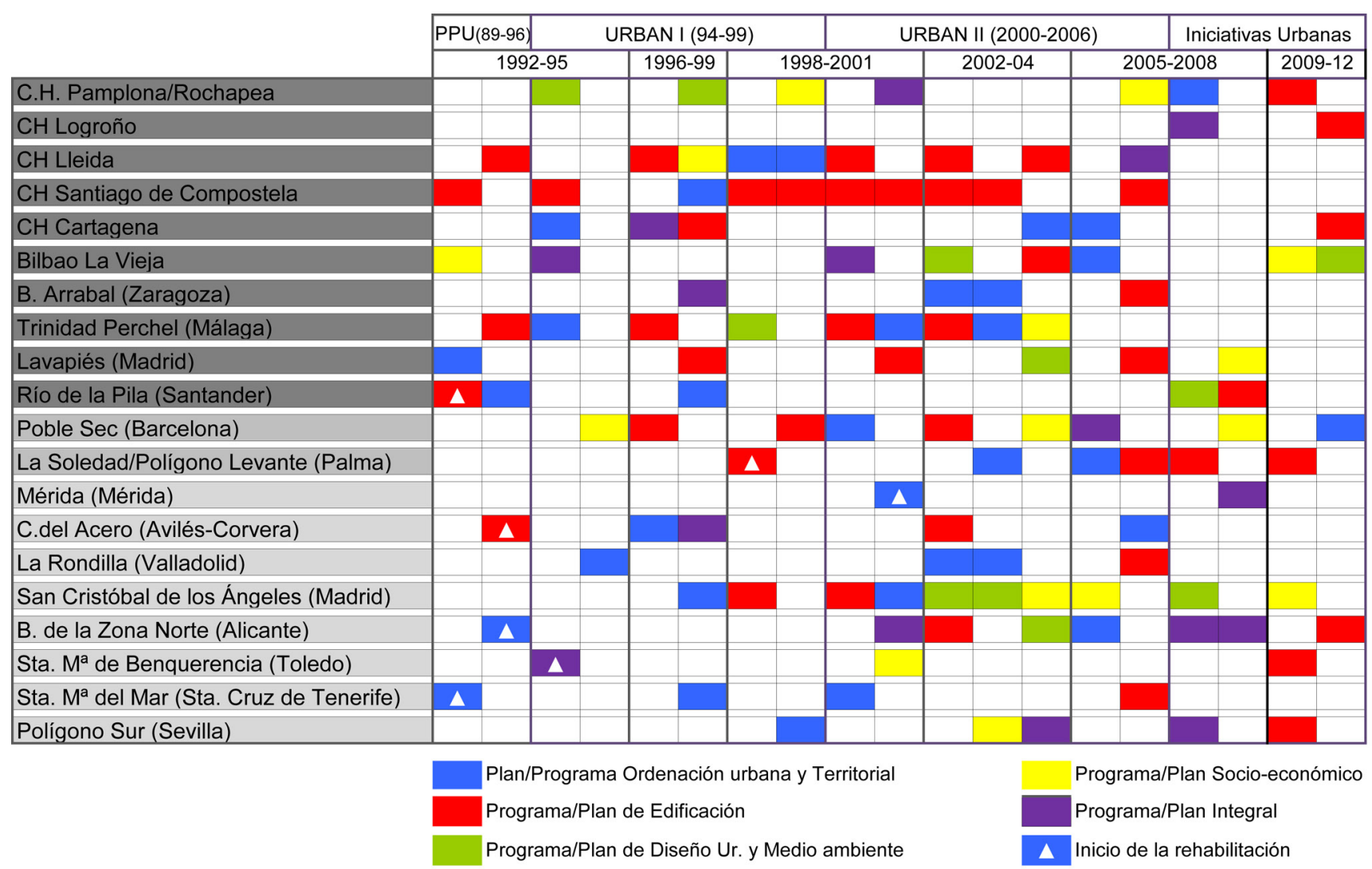

Figura 2. Actuaciones en las operaciones analizadas por área de actuación y año de inicio o aprobación, 1992-2012 (elaboración propia).

cal, que se dirigen principalmente a la reurbanización, pero que incorporan paulatinamente aspectos medioambientales, como en el caso del Plan Integral del río Arga en Pamplona (1996), o el proyecto Regen-Link (2001), sobre eficiencia energética y ambiental en edificios de viviendas en San Cristóbal de los Ángeles.

Se multiplican de forma notoria los planes con vocación integral, asociados a la primera convocatoria del programa URBAN I; aparecen hasta ocho planes de carácter integral en siete ciudades, seis de ellos con financiación de programas europeos. Es a finales del periodo cuando aparecen tres planes municipales, que plantean la coordinación de acciones y programas sectoriales con carácter de «integralidad»: el Plan Integral para la Recuperación del Casco Histórico (PICH) de Zaragoza de 1997 (incluido en 1998 en el programa URBAN I), el Plan Integral de Rehabilitación de Bilbao La Vieja, San Francisco y Zabala 2000-2004 (que contaba con la experiencia del Proyecto Piloto Urbano 1994-1997), y el Plan Municipal de Intervención Integral en Juan XXIII (2000-2006) de Alicante.

En la segunda década (2002-2012, aunque el análisis de casos sólo incluye hasta 2010) de este periodo, se aprueban también tres planes de vivienda, y dos programas europeos, URBAN II (2000-2006) e Iniciativa Urbana (2007-2013). Se aprecia un aumento del número de planes y programas, en mayor medida en los barrios que tuvieron su origen en el siglo xx y una mayor variedad en los temas a los que se dirigen. Disminuye la proporción de planes urbanísticos iniciados, y aumentan la de planes de vivienda, medioambientales, socioeconómicos e integrales.

Aunque muchas de las acciones dentro del área de Diseño Urbano y Medio Ambiente siguen estando vinculadas a la urbanización y a las infraestructuras, se detecta la aparición de planes in urban design and the local environment were also on the rise. These mainly tackled re-urbanization, but environmental aspects were gradually added, as in the case of the Comprehensive Plan of the Arga River in Pamplona (1996), or the Regen-Link project (2001), on energy and environmental efficiency in housing in San Cristóbal de los Ángeles.

Integrated urban plans associated with the first call of the URBAN I program multiplied significantly; eight integrated urban plans emerged in seven cities, six of them funded by European programs. Three municipal plans appeared at the end of this period proposing the coordination of integral actions and sector programs: the Comprehensive Plan for the Restoration of the Historic District (PICH) of Saragossa in 1997 (included in the URBAN I program in 1998), the Comprehensive Plan for the Renovation of Bilbao La Vieja, San Francisco and Zabala 200O-2004 (which took advantage of the experience of the 1994-1997 Urban Pilot Project), and the Municipal Plan for Comprehensive Intervention in Juan XXIII (2000-2006) in Alicante.

In the second decade of this period (2002-2012, even though the analysis of the cases only goes up to 2010), three more housing plans were approved, as well as two European programs, URBAN II (2000-2006) and Urban Initiative (2007-2013). The number of plans and programs increased, mostly in districts dating from the twentieth century, and a greater variety of intervention types was noted. The proportion of urban plans began to diminish, while housing, environmental, socio-economic and integrated urban plans grew. 
de movilidad (Lavapiés o Río de la Pila) o de recuperación de vías parque (Zona Norte de Alicante). Por otro lado, hay que destacar el aumento de planes del área socioeconómica que incluyen foros de participación con los vecinos en los que analizan y plantean las necesidades y prioridades del barrio. Disminuye el número de planes con financiación europea (URBAN), y surgen nuevos planes de iniciativa municipal o incluidos en planes autonómicos, como el Pla de Barris (en Lleida y Poble Sec). También hay que señalar la aparición de planes municipales en barrios especialmente estigmatizados, como el Plan Integral del Polígono Sur de Sevilla y el Plan Integral «Barrios Zona Norte de Alicante» que posteriormente obtuvieron financiación europea.

En resumen, entre 1992 y 2010, aunque continúan los procesos de intervención en los cascos históricos, crece la importancia de la rehabilitación en la periferia junto con una combinación de acciones, planes y programas más diversos dirigidos a la mejora de diferentes aspectos, como los sociales, económicos o medioambientales, que en el periodo anterior apenas tenían presencia. Se extienden los planes de carácter integral, tanto en centros como en periferias, principalmente a partir de la convocatoria URBAN I, aunque luego se consolidan a través de programas locales y autonómicos. Sin embargo, como han apuntado otros autores (7), la «integralidad» y éxitos parecen haber sido relativos ya fuera porque el programa inicialmente incluido en las memorias de estos planes no pudo realizarse (por falta de voluntad política, problemas de coordinación interadministrativa o presupuesto), o las acciones planteadas no han tenido los resultados esperados (por falta de coordinación, por no estar orientadas a los principales problemas del área, por falta de participación de los agentes implicados o por dificultades surgidas en el proceso). Se aprecian diferencias en la aplicación y resultados entre aquellos planes que se han limitado al desarrollo de las acciones financiadas por la convocatoria europea o autonómica, y la de aquellos que han sumado las acciones previstas y su financiación a un proyecto más amplio, con otras financiaciones como la del programa ARI y articulados a través del planeamiento urbanístico.

\section{DISCUSIÓN Y CONCLUSIONES}

Por un lado es necesario destacar cómo durante todo el ciclo analizado las políticas estatales en materia de rehabilitación en España, han sido subsidiarias de la política de apoyo a la construcción de nuevas viviendas contenida en los distintos planes de vivienda aprobados, y hasta el Plan 1992-1995 no aparecen las ARI como un programa específico. Aunque el marco de las ayudas estatales ha estado dirigido preferentemente a la rehabilitación de edificios, paulatinamente se han ido incorporando nuevos instrumentos, que junto a los programas autonómicos y europeos y a la acción de muchos municipios ha permitido el desarrollo de planes y programas de una complejidad creciente, que permiten disponer de una experiencia madura en materia de rehabilitación en áreas urbanas, con las que poder afrontar los retos de un nuevo ciclo que necesariamente pasará por la rehabilitación.

La rehabilitación urbana en España ha estado marcada por su heterogéneo desarrollo y por la amplia variedad de instrumentos de gestión, planes y programas desarrollados. Para su caracterización en la Figura 3, en forma de gráfico, hemos recogido la suma de actuaciones realizadas sobre los veinte casos que se han estudiado en profundidad. En ella puede verse la evolución del tipo de actuación en función del periodo de vigencia de los distintos planes de vivienda en forma de media anual, mientras que en la Tabla 3 vemos el número de actuaciones realizadas en función
Although many actions within the urban design and environmental area were still related to urbanization and infrastructures, mobility plans began to emerge (Lavapiés and Río de la Pila), as did the renovation of park boulevards (North Area of Alicante). On the other hand, there were more socio-economic plans, which included forums for residents to participate in where the district's needs and priorities were analyzed. The number of European funded programs (URBAN) dropped and new municipal initiatives emerged or were included in regional plans, such as the Pla de Barris (in Lleida and Poble Sec). Municipal plans were also established in especially stigmatized districts, such as the Comprehensive Plan of the Polígono Sur in Seville and the Comprehensive Plan of the North Area Districts in Alicante, which later obtained European funds.

To sum up, between 1992 and 2010, although intervention processes continued in historic centers, more importance was placed on rehabilitating the suburbs together with a combination of a variety of actions, plans and programs aimed at upgrading several social, economic and environmental aspects, which had hardly been present in the previous period. Integrated urban plans expanded, in both city centers and suburbs, mainly after the URBAN I call for proposals, although they were then consolidated in regional and local programs. However, as other authors have remarked (7), 'integrality' and success may have been relative, either because the program initially included in the reports of these plans was never carried out (due to the lack of political will, inter-administration coordination problems or budget constraints), or the proposed actions did not achieve the expected results (as they lacked coordination, did not target the area's main problems, the agents involved failed to participate, or issues arose during the process). Differences were noted in application and results between plans limited to the implementation of interventions funded by the $E U$ or the autonomous community, and those that had added the proposed actions and funding to a larger project with other funds, such as the ARI program, structured through urban planning.

\section{DISCUSSION AND CONCLUSIONS}

Throughout the period analyzed here, state urban renewal policies in Spain were subsidiary to the policy supporting the construction of new housing included in approved housing plans. ARI were not defined as a specific program until the 1992-1995 plan. Although the framework of subsidies has been mostly directed at renovating buildings, new instruments have gradually been added. These, together with regional and European programs and the intervention of many municipalities, have enabled not only the development of plans and programs of increasing complexity, but also mature experiences in the field of urban renewal that we can draw on to face the challenges of a new cycle that is bound to include renovation.

Urban renewal in Spain has been characterized by nonuniform development and the implementation of a wide variety of management instruments, plans and programs. To produce the graph in Figure 3, we have collated all the interventions in the twenty cases we have studied in-depth. 


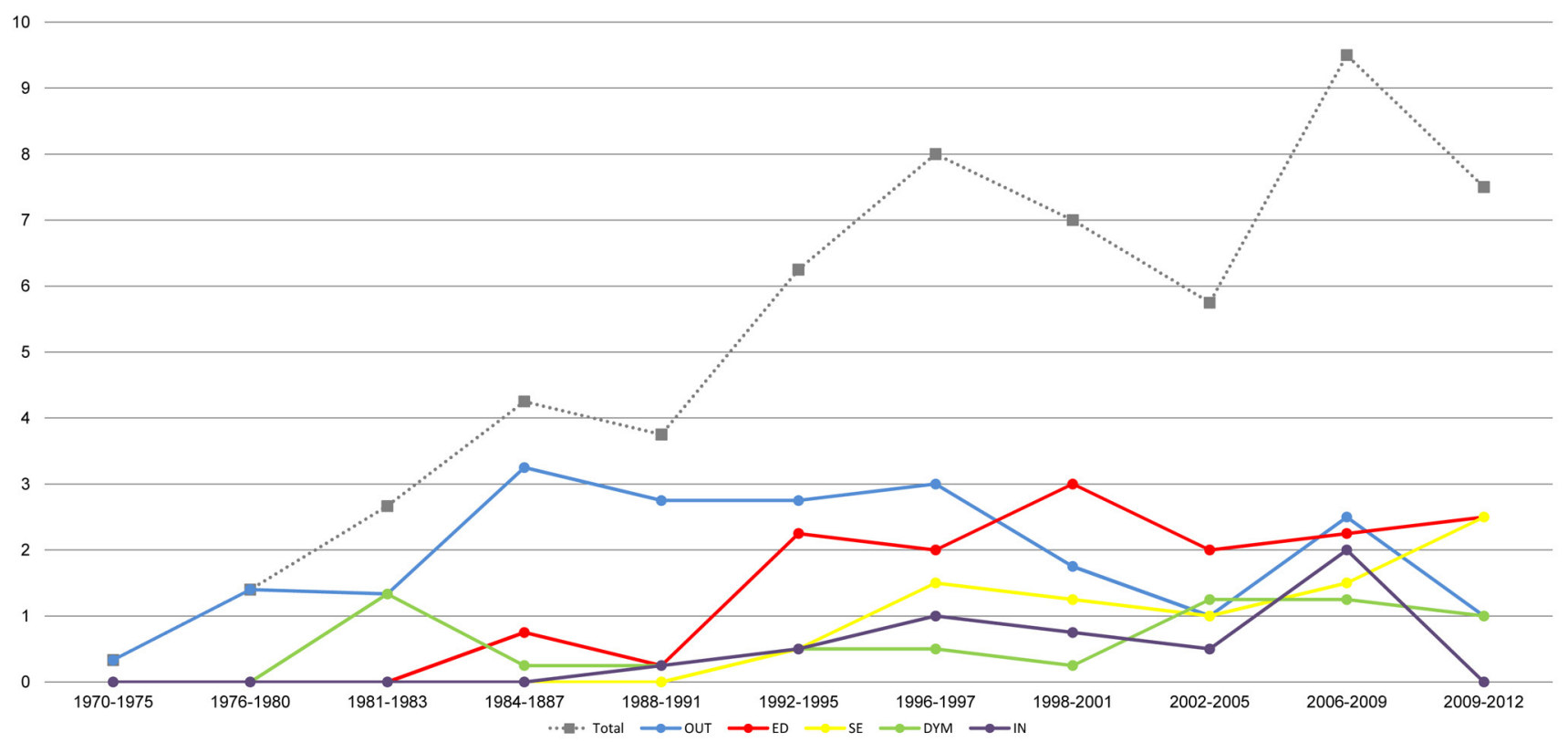

Figura 3. Número de programas y planes iniciados por año según los periodos de los planes estatales de vivienda por área principal en los 20 casos analizados (elaboración propia).

de las dimensiones básicas de la rehabilitación urbana: Ordenación Urbana y Territorial (OUT), Diseño Urbano y Medio Ambiente Local (DYM), Edificación (ED) y Socio-economía (SE).

Como ya hemos indicado anteriormente diferenciamos en nuestro estudio dos periodos: antes de 1992 y de 1992-2012 (aunque el estudio de casos termina en 2010). En el primer periodo (antes de 1992) nos encontramos en un momento fundacional de la rehabilitación, en el que aún la figura del ARI no tiene programa propio dentro de los planes de vivienda. Doce de las veinte experiencias analizadas tienen su origen en este periodo y de ellas ocho se desarrollan sobre cascos históricos. Desde el punto de vista de las dimensiones que hemos determinado como básicas en las operaciones de rehabilitación integrada, la mayoría de los programas y proyectos existentes (36) están relacionados con el planeamiento urbanístico, suponiendo el $75 \%$ del total. En segundo lugar aparecen los programas de intervención en la edificación (7), y en menor medida las operaciones de diseño urbano y medio ambiente local (4). No encontramos ninguna asociada aún a la dimensión socioeconómica, aunque hay que destacar la aparición del primer programa con carácter integral, de Santiago de Compostela.
The figure shows the evolution of the interventions over the period the housing plans were in effect as an annual average. Table 3 shows the number of interventions in each of the four basic dimensions of Integrated Urban Regeneration: urban and territorial planning (OUT), urban design and local environment (DYM), buildings (ED) and socio-economics (SE).

As mentioned above, our study identifies two periods, before 1992 and from 1992 to 2012 (although the case study ends in 2010). In the first period (before 1992) there is a crucial moment for the foundations of urban regeneration, when the ARI still do not have their own specific program within housing plans. Twelve of the twenty experiences analyzed date from this period, and eight of these were implemented in historic centers. Concerning the dimensions we have determined as basic in integrated urban regeneration interventions, most of the programs and existing projects (36) are related to urban planning (75 per cent of the total). Intervention programs in buildings come second (7), followed by urban design and local environmental actions (4). We have not yet found any association with the socio-

Tabla 3. Número de planes/programas iniciados por periodo y área temática principal.

\begin{tabular}{|c|c|c|c|c|c|c|c|c|c|c|c|c|c|c|}
\hline & $\begin{array}{l}1978- \\
1980\end{array}$ & $\begin{array}{c}\text { PV 1981- } \\
1983\end{array}$ & $\begin{array}{c}\text { PV 1984- } \\
1987\end{array}$ & $\begin{array}{c}1988- \\
1991\end{array}$ & $\begin{array}{l}\text { Total } \\
1978- \\
1991\end{array}$ & $\%$ & $\begin{array}{c}\text { PV 1992- } \\
1995\end{array}$ & $\begin{array}{c}\text { PV 1996- } \\
1999\end{array}$ & $\begin{array}{c}\text { PV 1998- } \\
2001\end{array}$ & $\begin{array}{c}\text { PV } \\
2002- \\
2005 \\
\end{array}$ & $\begin{array}{c}\text { PV } \\
2005- \\
2008 \\
\end{array}$ & $\begin{array}{c}\text { PV } \\
2009- \\
2012 \\
\end{array}$ & $\begin{array}{l}\text { Total } \\
1992- \\
2010\end{array}$ & $\%$ \\
\hline OUT & 7 & 4 & 14 & 11 & 36 & 75 & 11 & 7 & 6 & 6 & 11 & 1 & 42 & 26 \\
\hline ED & 0 & 3 & 3 & 1 & 7 & 15 & 10 & 4 & 15 & 12 & 13 & 8 & 62 & 38 \\
\hline SE & 0 & o & 0 & o & 0 & o & 2 & 3 & 5 & 5 & 7 & 5 & 27 & 17 \\
\hline DYM & o & 1 & 1 & 2 & 4 & 8 & 1 & 1 & 2 & 4 & 5 & 2 & 15 & 9 \\
\hline INT & o & o & o & 1 & 1 & 2 & 2 & 3 & 3 & 1 & 8 & 0 & 17 & 10 \\
\hline Total & 7 & 8 & 18 & 15 & 48 & 100 & 26 & 18 & 31 & 28 & 44 & 16 & 163 & 100 \\
\hline
\end{tabular}

Leyenda: PV: Plan de vivienda estatal; OUT: Planes /Programas del área Ordenación Urbana y Territorial; ED: Planes /Programas del área de edificación; SE: Planes/Programas del área Socio- económica; DYM: Planes /Programas del área de Diseño Urbano y Medio ambiente; INT: Planes/programas de carácter integral (elaboración propia). 
En el segundo periodo (1992-2012), cuando los ARI cuentan ya con programas propios dentro de los planes de vivienda, se produce un incremento significativo del número de programas en las experiencias analizadas, llegando a 163, casi el cuádruple de periodo anterior. Desde el punto de vista de las dimensiones de la rehabilitación integral, hay que señalar una disminución del peso de las operaciones relacionadas con el planeamiento urbanístico (42) que suponen tan solo el $26 \%$ del total. Son las operaciones de intervención en la edificación las que lideran el proceso con 62 programas, el $38 \%$ del total. Los planes y proyectos centrados en la dimensión socioeconómica surgen con fuerza en el periodo con 27 operaciones que suponen un $17 \%$, frente a su inexistencia en el periodo anterior. Las operaciones de intervención en la escala del diseño urbano y el medio ambiente local empatan con las operaciones de carácter integral con 16 planes o proyectos cada una. El periodo se caracteriza por la intervención en la periferia, con seis de las ocho operaciones iniciadas. El incremento de los programas socioeconómicos se debe tanto a los programas de revitalización económica y comercial de las zonas centrales, como a los programas sociales o de «participación», desarrollados principalmente en los barrios de la periferia, que caracterizados por importantes carencias y problemas y con una alta vulnerabilidad socio-económica, introducen la necesidad de otro tipo de acciones. Directamente vinculados a la aparición de los programas de iniciativa comunitaria, se empiezan a desarrollar en esta época planes con planteamientos más integrales, principalmente en cascos pero también en la periferia.

Finalmente, tras un descenso en el número de programas iniciados entre 2002 y 2005, vuelve a producirse en el periodo 2005-2008 un incremento significativo, en los programas iniciados de todas las áreas. Es especialmente llamativa la consolidación de los programas sociales y de carácter integral. Sin embargo, más allá de este aumento en el número de programas iniciados, que demuestra cierto incremento del interés de las administraciones por la rehabilitación, hay que tener en cuenta el contenido de estos, su aplicación real, y principalmente la inversión dedicada a cada uno de los programas. Al finalizar el análisis en 2011, no están incluidos los programas iniciados entre este año y el momento actual, aunque los datos parecen apuntar a un descenso del número de programas y a la disminución o finalización de alguno de estos por cuestiones económicas.

En cualquier caso, cabe señalar que la práctica de la Rehabilitación Urbana Integrada, no puede entenderse como un proyecto limitado en el tiempo, sino como un proceso. Podemos ver como en todos los casos analizados es así, y podemos establecer que los casos con mejores resultados son aquellos, en los que la intervención se ha producido como un proceso de mejora, en el que cada actuación y proyecto se desarrollaba en más de una de las áreas establecidas como básicas y en el que el fin de un programa era la antesala del comienzo de otro. economic dimension, although the first integral program took place in Santiago de Compostela.

In the second period (1992-2012) when the ARI already had their own programs within housing plans, the number of programs in the cases we analyzed rose significantly to 163, almost four times the amount in the previous period. Regarding the dimensions of integrated urban regeneration, urban planning interventions (42) became less important (only 26 per cent of the total). Plans and projects in the socioeconomic dimension rose sharply with 27 interventions (17 per cent) in the period, compared with none in the previous period. Integral interventions and urban design and local environment interventions both have 16 plans or projects each. This period is defined by interventions in the suburbs; six out of the eight started. Socio-economic programs have increased due to both the economic and commercial revitalization programs in central areas and the social or participation programs implemented mainly in suburbs. As the latter suffer from major deficiencies, problems and high socio-economic vulnerability, a different type of action is needed. Directly related to the emergence of community initiative programs, more integral interventions began to be implemented at that time, mainly in city centers, but also in the suburbs.

Finally, after the number of programs started to decrease between 2002 and 2005, there was a significant rise in the programs commenced in every area in the 2005-2008 period. The consolidation of integral and social programs social programs was particularly remarkable. However, despite this rise in the number of programs, which proves that local governments were showing more interest in renovation, we must consider their content, how they were implemented and, above all, the investment spent on each of the programs. As the analysis concludes in 2011, no programs that started between that year and the present are included, although data seem to indicate a drop in the number of programs, and some have been slimmed down or ended for financial reasons.

Integrated Urban Regeneration practice cannot be understood as a project with time constraints since it is a process. All the cases we have analyzed prove this point, and the ones with better results are those in which the intervention was part of an upgrade process, every action or project was implemented in more than one of the established basic areas, and the end of one project marked the beginning of the next.

\section{REFERENCIAS}

(1) Naredo, J. M. (2004). Perspectivas de la vivienda. Información Comercial Española, ICE: Revista de economía, 815: 143154.

(2) Pérez, T., Rodríguez, M., Blanco, Á. (2011). Política de gasto en vivienda. España, 2010. Papeles de Trabajo del Instituto de Estudios Fiscales, 2011(1): 1-57.

(3) Fernández, A. (2004). Veinticinco años de política de vivienda en España. (1976-2001): una visión panorámica. Información Comercial Española, ICE: Revista de economía, 816: 145-161. 
(4) Hernández, A., García, C. (2014). Magnitudes de 20 años de planes y programas de rehabilitación y regeneración urbana. Ciudad y territorio: Estudios territoriales, 2014(179): 184-191.

(5) Hernández Aja, A., Vázquez Espí, M., García Madruga, C., Matesanz Parellada, A., Moreno García, E., Alguacil Gómez, J., Camacho Gutiérrez, J. (2013) Análisis Urbanístico de Barrios Vulnerables. http://habitat.aq.upm.es/bbvv/.

(6) Ramos, J., García Tobío, F., Camiragua, I., Panero, A., Allegue, X. S., Fernández Hermida, R. (1995) La oficina municipal de conservación y rehabilitación de la ciudad histórica de Santiago de Compostela (Galicia, España). Informes de la Construcción, 47(439):77-89.

(7) Castrillo, M. (2013). La réhabilitation urbaine: une politique impossible?. En Coudroy de Lille,L.,Vaz, C., Vorms, Ch. (Dir.) L'Urbanisme espagnol depuis les années 1970. La ville la démocratie et le marché (pp. 113-126). Rennes: Presses Universitaires de Rennes. 